\title{
ANALISIS TINGKAT BERPIKIR KREATIF SISWA DITINJAU DARI GAYA KOGNITIF FIELD DEPENDENT DAN FIELD INDEPENDENT
}

\author{
Mirsa Prihatiningsih ${ }^{1}$, Novisita Ratu ${ }^{2}$ \\ 1,2 Univeritas Kristen Satya Wacana, J1. Diponegoro 52-60 Salatiga \\ 202016046@student.uksw.edu
}

\begin{abstract}
This research is a qualitative descriptive. The purpose of this research was to describe the level of creative thinking ability possessed by students with the Field Dependent (FD) cognitive style and students with the Field Independent (FI) cognitive style in solving the problem of the area of the combined flat shape (triangle and quadrilateral). The level of creative thingking ability observed based on the assessment of fluency, flexibility, and novelty indicators are TKBK 0 , TKBK 1, TKBK 2, TKBK 3 and TKBK 4 . The subject of this research were 3 students with FD cognitive style and 3 students with FI cognitive style class VIII A of SMP Negeri 6 Salatiga. Sampling was done by purposive sampling technique. Data is collected by the Group Embedded Figures Test (GEFT), creative thinking test, and interview. The result of data analysis are as follows: 1) The level of Creative Thinking Ability owned by subjects with FD cognitive style in solving mathematical problems namely TKBK 1 (less creative) and TKBK 3 (creative), 2) The level of Creative Thinking Ability owned by subjects with FI cognitive style in solving mathematical problems namely TKBK 1 (less creative) and TKBK 2 (quite creative). Keywords: Cognitive Style, Field Dependent, Field Independent, Level of Creative Thinking
\end{abstract}

\begin{abstract}
Abstrak
Penelitian ini merupakan penelitian diskriptif kualitatif. Tujuan penelitian ini untuk mendiskripsikan tingkat kemampuan berpikir kreatif yang dimiliki siswa dengan gaya kognitif Field Dependent (FD) dan siwa dengan gaya kognitif Field Independent (FI) dalam menyelesaikan masalah luas gabungan bangun datar (segitiga dan segiempat). Tingkat Kemampuan Berpikir Kreatif (TKBK) yang diamati berdasarkan penilaian indikator kefasihan, fleksibilitas, dan kebaruan yaitu TKBK 0, TKBK 1, TKBK 2, TKBK 3, dan TKBK 4. Subjek penelitian ini yaitu 3 siswa dengan gaya kognitif FD dan 3 siswa dengan gaya kognitif FI kelas VIII A SMP Negeri 6 Salatiga. Pengambilan sampel dilakukan dengan teknik purposive sampling. Pengambilan data dilakukan dengan tes Group Embedded Figures Test (GEFT), tes berpikir kreatif, dan wawancara. Hasil analisis data sebagai berikut: 1) Tingkat Kemampuan Berpikir Kreatif yang dimiliki subjek dengan gaya kognitif FD dalam menyelesaikan masalah matematika yaitu TKBK 1 (kurang kreatif) dan TKBK 3 (kreatif), 2) Tingkat Kemampuan Berpikir Kreatif yang dimiliki subjek dengan gaya kognitif FI dalam menyelesaikan masalah matematika yaitu TKBK 1 (kurang kreatif) dan TKBK 2 (cukup kreatif).
\end{abstract}

Kata kunci: Field Dependent, Field Independent, Gaya Kognitif, Tingkat Kemampuan Berpikir Kreatif

\section{PENDAHULUAN}

Mempersiapkan dan melahirkan siswa yang memiliki karakter aktif dan positif perlu adanya sistem pendidikan yang terus mengalami perubahan serta perkembangan. Sistem pendidikan terdiri dari beberapa cakupan yang menunjang untuk tercapainya pendidikan yang diharapkan. Cakupan yang ada dalam sistem pendidikan salah satunya adalah kurikulum yang merupakan aturan dan rancangan yang diterapkan sebagai pedoman dalam mencapai suatu tujuan pendidikan (Depdiknas, 2013). Kurikulum yang dipakai sebagai Standar Pendidikan Nasional yaitu Kurikulum 2013 atau K-13 yang mengedepankan pendidikan berkarakter dengan empat aspek penilaian, yaitu keterampilan, pengetahuan, sosial, dan spiritual. Pelaksanaan K-13 dalam pembelajaran matematika diharapkan mampu membangun dan mengembangkan karakter dan kepribadian siswa yang positif, serta kemampuan siswa, berdasarkan muatan yang sudah ditetapkan. Muatan yang terdapat pada mata 
pelajaran matematika bertujuan untuk membekali siswa agar mampu berpikir secara sistematis, kritis, kreatif, logis, dan analitis, serta dapat bersikap positif (Permendikbud, 2016 Nomor 021). Pencapaian kompetensi yang ada dalam pembelajaran matematika maupun dalam segala bidang di kehidupan sehari-hari, sangat diperlukan adanya peran kemampuan berpikir kreatif (Santoso, 2014). Berpikir kreatif merupakan suatu langkah atau cara yang digunakan dalam menyikapi atau menghadapi perkembangan dan perubahan pada persoalan atau permasalahan yang lebih sulit (Putri, 2018). Kemampuan berpikir kreatif juga diperlukan untuk menentukan strategi yang tepat dalam menyelesaikan beragam permasalahan matematika dari yang mudah hingga permasalahan yang rumit.

Kemampuan berpikir kreatif yang dimiliki seseorang dapat diukur dengan pedoman yang sudah ada. Silver (1997) menyatakan bahwa untuk mengukur kemampuan berpikir kreatif seseorang digunakan Tes Torrance atau disebut "The Torrance Test of Creative Thingking (TTCT)". Pedoman yang digunakan untuk mengukur dan mengembangkan berpikir kreatif yaitu dengan karakteristik kemampuan berpikir kreatif dengan tiga indikator yang dinilai. Tiga indikator yang dinilai dalam kemampuan berpikir kreatif menurut Silver yang diadobsi Siswono (2011) yaitu kefasihan fleksibilitas, dan kebaruan terlihat pada tabel 1.

Tabel 1.

Karakteristik indikator kemampuan berpikir kreatif

\begin{tabular}{|c|l|}
\hline $\begin{array}{c}\text { Karakteristik Kemampuan } \\
\text { Berpikir Kreatif }\end{array}$ & \multicolumn{1}{|c|}{ Indikator Kemampuan Berpikir Kreatif } \\
\hline Kebaruan & $\begin{array}{l}\text { Siswa mampu menyajikan solusi asli yang berbeda-beda } \\
\text { namun bernilai benar atau mampu menunjukkan satu } \\
\text { jawaban yang tidak biasa dilakukan oleh siswa pada } \\
\text { tingkat pengetahuannya dalam menyelesaikan masalah. }\end{array}$ \\
\hline Fleksibilitas & $\begin{array}{l}\text { Siswa mampu memecahkan masalah menggunakan } \\
\text { berbagai metode atau cara. }\end{array}$ \\
\hline Kefasihan & $\begin{array}{l}\text { Siswa mampu menunjukkan banyak/beragam jawaban } \\
\text { dalam memecahkan permasalahan. }\end{array}$ \\
\hline
\end{tabular}

Kemampuan berpikir kreatif yang memiliki tingkatan yang berbeda-beda telah dinyatakan oleh Siswono (2006) terlihat pada tabel 2. Karakteristik dalam mempelajari matematika pada masing-masing siswa ini memeperlihatkan adanya derajat atau tingkatan. Seperti halnya, penelitian yang dilakukan oleh Santoso (2014) menunjukkan bahwa terdapat perbedaan karakteristik kemampuan berpikir kreatif, dari lima subjek penelitiannya diperoleh subjek yang memiliki TKBK (Tingkat Kemampuan Berpikir Kreatif) 4 mampu memunculkan semua indikator berpikir kreatif. Subjek TKBK 3 dapat memunculkan indikator kefasihan dan fleksibiltas. Subjek dengan TKBK 2 dapat memunculkan indikator fleksibilitas 
saja. Subjek TKBK 1 hanya menunjukkan indikator kefasihan. Subjek TKBK 0 tidak mampu menunjukkan semua indikator berpikir kreatif dalam penyelesaian soal.

\section{Tabel 2.}

Tingkat kemampuan berpikir kreatif

\begin{tabular}{|l|l|}
\hline \multicolumn{1}{|c|}{$\begin{array}{c}\text { Kingkat Kemampuan Berpikir } \\
\text { TKBK } 4 \text { (Sangat Kreatif) }\end{array}$} & \multicolumn{1}{c|}{ Karakteristik Kemampuan Berpikir Kreatif } \\
\hline memenuhi kebaruan, fleksibilitas, dan kefasihan. \\
\hline TKBK 3 (Kreatif) & $\begin{array}{l}\text { Siswa dalam menyelesaikan masalah mampu memunculkan } \\
\text { kebaruan dan fleksibilitas tanpa kefasihan atau mampu } \\
\text { menunjukkan kebaruan dan kefasihan tetapi tanpa fleksibilitas. }\end{array}$ \\
\hline TKBK 2 (Cukup Kreatif) & $\begin{array}{l}\text { Siswa mampu memunculkan kebaruan namun tidak fleksibel } \\
\text { atau fasih, atau menunjukkan fleksibilitas dan kefasihan tanpa } \\
\text { kebaruan dalam menyelesaikan masalah. }\end{array}$ \\
\hline TKBK 1 (Kurang Kreatif) & $\begin{array}{l}\text { Siswa dalam menyelesaikan masalah hanya mampu } \\
\text { memunculkan indikator fleksibilitas atau kefasihan. }\end{array}$ \\
\hline TKBK 0 (Tidak Kreatif) & $\begin{array}{l}\text { Siswa tidak dapat mengajukan atau memberikan solusi yang } \\
\text { memenuhi kebaruan, fleksibilitas dan kefasihan dalam } \\
\text { memecahkan permasalahan. }\end{array}$ \\
\hline
\end{tabular}

Setiap siswa mempunyai bakat, kemampuan, dan pengelompokan gaya kognitif berbeda-beda yang memungkinkan siswa memiliki gambaran berpikir kreatif dalam penyelesaian masalah yang berbeda pula, dengan kata lain kemampuan berpikir kreatif siswa yang dihasilkan akan tergantung dari gaya kognitif yang dimilikinya (Rahmatina, 2014). Gaya kognitif berdasarkan hasil penelitian oleh Witkin dalam Ghufron (2012) dapat dikelompokkan menjadi dua yaitu gaya kognitif field dependent (FD), ketika seseorang merespon dirinya cenderung dipengaruhi oleh lingkungan, dan field independent (FI) ketika individu mereaksikan sebagian besar tingkah laku dirinya cenderung tidak dipengaruhi oleh lingkungan. Pada penelitian yang dilakukan Argarini (2014) di SMP Negeri 1 Kragan kelas 7 dengan 4 siswa sebagai subjek penelitian menyimpulkan bahwa, 2 subjek bergaya kognitif FD menunjukkan indikator kefasihan tanpa kebaruan dalam penyelesaian masalah dan fleksibilitas tidak terpenuhi dalam pengajuan masalah. 2 subjek bergaya kognitif FI menunjukkan indikator kefasihan dan fleksibilitas, namun dalam pengajuan pertanyaan fleksibilitas tidak terpenuhi, serta subjek memunculkan indikator kebaruan, tetapi dalam pengajuan masalah indikator ini tidak muncul.

Untuk mengukur dan mengelompokkan gaya kognitif FD dan FI menggunakan Group Embedded Figures Test (GEFT) yang dicetuskan oleh Witkin dan diadobsi oleh Kristanto (2016). 
Ketentuan penilaian pada GEFT yaitu skor 1 untuk jawaban yang benar dan skor 0 untuk jawaban yang salah, dengan total skor yang diperoleh 0 sampai 18. Apabila skor yang diperoleh 10 sampai 18, maka subjek memiliki gaya kognitif FI dan apabila skor yang diperoleh 0 sampai 9, maka subjek bergaya kognitif FD.

Berdasarkan uraian di atas, penelitian ini bermaksud untuk mengetahui tingkat berpikir kreatif siswa ditinjau dari gaya kognitif (field dependent dan field independent) yang dimiliki dalam meyelesaikan masalah luas gabungan bangun datar (segitiga dan segiempat).

\section{METODE}

Penelitian ini merupakan penelitian diskriptif kualitatif yang bertujuan untuk mendiskripsikan tingkat berpikir kreatif siswa yang ditinjau dari gaya kognitif Field Dependent (FD) dan Field Independent (FI) pada materi luas gabungan bangun datar (segitiga dan segiempat). Penelitian ini dilakukan di SMP Negeri 6 Salatiga pada semester I Tahun Ajaran 2019/2020 di bulan Desember 2019. Pemilihan subjek pada penelitian ini menggunakan teknik purposive sampling yang merupakan teknik dalam pengambilan sampel sumber data melalui pertimbangan tertentu (Sugiyono, 2012) Subjek penelitian ini adalah 6 siswa kelas VIII A, 3 subjek bergaya kognitif Field Dependent dan 3 subjek bergaya kognitif Field Independent, dengan masing-masing berkemampuan matematika tinggi, sedang, dan rendah.

Pengumpulan data pada penelitian ini melalui tes kemampuan berpikir kreatif dan tes GEFT, wawancara semiterstruktur, dan dokumentasi. Instrumen yang digunakan peneliti yaitu yang pertama instrumen tes GEFT terdiri dari 18 butir soal. Instrumen kedua yaitu, instrumen tes kemampuan berpikir kreatif (tipe soal open ended) terdiri dari 2 soal tentang luas gabungan bangun datar (segitiga dan segiempat) yang mengacu pada tiga indikator kemampuan berpikir kreatif dari Siswono (2011) yaitu fleksibilitas, kebaruan, dan kefasihan. Instrumen ketiga, yaitu pedoman wawancara semiterstruktur dengan mengajukan pertanyaan yang disesuaikan dengan alternatif jawaban yang diberikan subjek. Data dokumentasi berupa hasil belajar matematika subjek semester I untuk menentukan kemampuan matematika tinggi, sedang, dan rendah.

Analisis data yang digunakan pada penelitian ini menurut Miles dan Huberman, yaitu reduksi data, penyajian data, penarikan kesimpulan (Sugiyono, 2012). Pertama Hasil tes GEFT, tes kemampuan berpikir kreatif dan wawancara direduksi atau dilakukakan penyederhanaan atau pemusataan data. Selanjutnya analisis data dilakukan pada hasil tes GEFT, tes kemampuan berpikir kreatif, dan hasil wawancara. Hasil analisis data selanjutnya disajikan melalui pendiskripsian data dalam bentuk teks naratif, grafik/tabel, maupun hubungan antar kategori. Terakhir penarikan kesimpulan berdasarkan pengumpulan data di lapangan baik dari tes, wawancara, maupun dokumentasi yang konsisten dan valid, sehingga kesimpulan yang dikemukakan kredibel atau dapat dipercaya. 


\section{HASIL}

Penelitian ini memilih 6 subjek dengan kriteria kemampuan matematika tinggi, sedang dan rendah yang berdasarkan hasil Penilaian Akhir Semester mata pelajaran matematika serta berdasarkan hasil tes GEFT. Hasil tes GEFT yang telah dilakukan oleh 28 siswa kelas VIII A SMP Negeri 6 Salatiga, diketahui 5 siswa memiliki gaya kognitif FD dan 23 siswa memiliki gaya kognitif FI seperti terlihat pada tabel 3. Terpilih 3 subjek bergaya kognitif FI, yaitu DHS berkemampuan matematika tinggi, VSW berkemampuan matematika sedang, dan CRD berkemampuan matematika rendah, serta 3 subjek bergaya kognitif FD, yaitu WDA berkemampuan matematika tinggi, GAN berkemampuan matematika sedang, dan MRKD berkemampuan matematika rendah.

\section{Tabel 3.}

Hasil Tes GEFT

\begin{tabular}{|c|c|c|}
\hline GAYA KOGNITIF & SKOR BENAR & BANYAK SISWA \\
\hline \multirow{10}{*}{ FD } & 0 & - \\
\hline & 1 & - \\
\hline & 2 & - \\
\hline & 3 & - \\
\hline & 4 & - \\
\hline & 5 & - \\
\hline & 6 & 2 \\
\hline & 7 & 1 \\
\hline & 8 & - \\
\hline & 9 & 2 \\
\hline \multirow{9}{*}{ FI } & 10 & - \\
\hline & 11 & - \\
\hline & 12 & - \\
\hline & 13 & 1 \\
\hline & 14 & 1 \\
\hline & 15 & - \\
\hline & 16 & 6 \\
\hline & 17 & 12 \\
\hline & 18 & 3 \\
\hline
\end{tabular}

Hasil tes kemampuan berpikir kreatif dari keenam subjek tersebut dianalisis dengan 3 indikator kemampuan berpikir kreatif untuk mengelompokkan subjek kedalam 5 kategori Tingkat Kemampuan Berpikir Kreatif (TKBK), berikut pembahasaannya:

\section{Subjek DHS Berkemampuan Matematika Tinggi Dengan Gaya Kognitif FI}

Subjek DHS dalam mengerjakan soal nomor 1 memberikan jawaban sebanyak 2 gambar gabungan bangun datar yang berbeda seperti terlihat pada gambar 1. Bangun pertama, subjek menggambar gabungan dari bangun persegi dan segitiga sama kaki. Bangun kedua, subjek menggambar gabungan dari segitiga sama kaki dan jajargenjang. Subjek dalam menggambar gabungan bangun terseut terlebih dahulu menentukan bentuk bangun dan ukurannya kemudian menghitung luasnya hingga diperoleh luas sesuai dengan soal. Berdasarkan hasil tersebut subjek DHS mampu memberikan 
beragam jawaban/solusi, namun solusi yang diberikan subjek terbilang masih umum. Dengan kata lain sujek mampu menunjukkan indikator kefasihan namun tidak menunjukkan kebaruan dalam menyelesaikan soal nomor 1 .

Penyelesaian soal nomor 2 subjek DHS memberikan dua cara/metode yang berbeda, namun bernilai benar dengan luas total yang diperoleh sesuai dengan soal seperti pada gambar 1. Hal yang pertama dilakukan subjek DHS dalam menjawab soal ini adalah memecahkan atau membagi bangun pada soal menjadi beberapa bangun agar dapat dihitung menggunakan pengetahuan awal yang sudah subjek dapatkan dalam pembelajaran matematika (rumus-rumus bangun datar). Cara pertama subjek menjumlahkan luas bangun persegi panjang dan segitiga. Cara kedua, subjek memandang bahwa bangun tersebut merupakan bangun persegi panjang yang tidak utuh, terdapat bagian yang hilang berbentuk trapesium. Sehingga, pada cara kedua subjek menggunakan bangun persegi panjang utuh dikurangi trapesium. Hasil tes tertulis tersebut memperlihatkan bahwa subjek DHS mampu memenuhi indikator fleksibilitas dalam menyelesaikan soal, subjek mampu memberikan lebih dari satu cara/metode bernilai benar pada pengerjaannya. Namun, jawaban yang diberikan subjek DHS ini masih terbilang umum atau tidak menunjukkan solusi yang baru. Dengan kata lain subjek belum mampu menunjukan indikator kebaruan dalam menyelesaikan soal nomor 2.

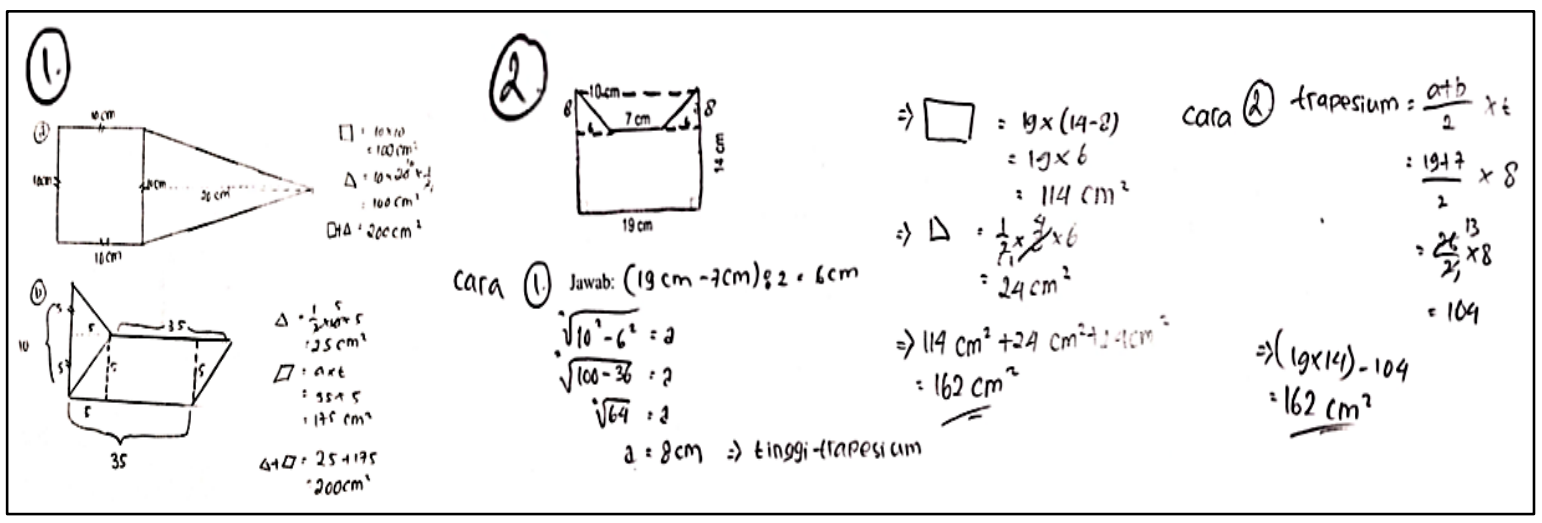

Gambar 1. Jawaban subjek DHS

Berdasarkan hasil analisa subjek DHS yang bergaya kognitif FI memiliki TKBK 2 (cukup kreatif). Hal ini ditunjukkan bahwa subjek hanya mampu memunculkan indikator fleksibilitas dan kefasihan tanpa kebaruan dalam menyelesaiakan permasalahan.

\section{Subjek VSW Berkemampuan Matematika Sedang Dengan Gaya Kognitif FI}

Pada gambar 2 tersebut, terlihat bahwa subjek VSW mampu memberikan dua gambar gabungan bangun datar (segitiga dan segiempat). Gabungan bangun pertama yang dibuat oleh subjek VSW adalah segitiga sama kaki dan persegi. Bangun kedua yang dibuat subjek yaitu gabungan dari trapesium dan segitiga sama kaki. Hal in menunjukkan bahwa subjek fasih dalam menyelesaikan soal terlihat mampu memberikan lebih dari satu jawaban, namun jawaban yang diberikan tidak baru. Dengan kata lain, subjek memunculkan indikator kefasihan tanpa kebaruan dalam menyelesaikan soal nomor 1 ini. 
Hasil pengerjaan soal nomor 2 oleh subjek VSW seperti pada gambar 2, terlihat bahwa subjek VSW dalam menentukan luas dari bangun tersebut menggunakan dua cara. Cara pertama, subjek VSW menjumlahkan luas dua bangun segitiga dan bangun persegi panjang. Cara kedua, subjek menjumlahkan luas dua bangun trapesium dan persegi panjang. Berdasarkan hal tersebut, subjek mampu menunjukkan indikator fleksibilitas, akan tetapi jawaban yang diberikan subjek masih terbilang umum. Jadi pada penyelesaian soal nomor 2 ini subjek belum mampu menunjukkan indikator kebaruan.

Berdasarkan hasil analisa subjek VSW yang bergaya kognitif FI memiliki TKBK 2 (cukup kreatif). Hal ini ditunjukkan bahwa subjek hanya mampu memunculkan indikator fleksibilitas dan kefasihan tanpa kebaruan dalam menyelesaiakan permasalahan.

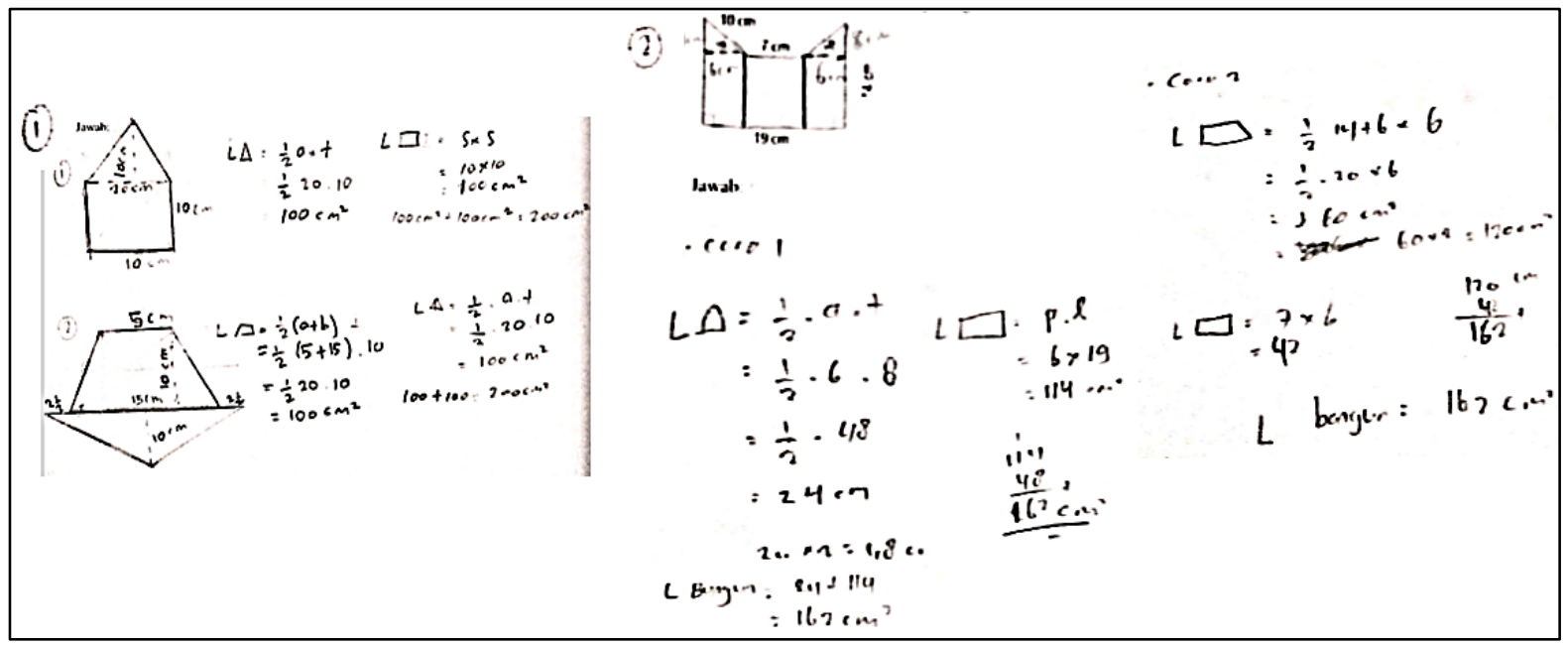

Gambar 2. Jawaban subjek VSW

\section{Subjek CRD Berkemampuan Matematika Rendah Dengan Gaya Kognitif FI}

Subjek CRD dalam pengerjaan soal nomor 1 terlihat pada gambar 3 hanya dapat memberikan satu jawaban bernilai benar. Subjek menggambar gabungan bangun segitiga sama sisi, persegi panjang dan dua segitiga siku-siku. Hasil tes tertulis tersebut menunjukkan bahwa subjek CRD belum mampu memunculkan indikator kefasihan dalam menyelesaikan soal hasil tes tertulis, dikarenakan subjek CRD hanya mampu memberikan 1 jawaban yang bernilai benar. Jawaban yang diberikan subjek CRD pada soal nomor 1 ini masih terbilang umum dan bukan merupakan solusi yang baru, maka pada pengerjaan soal ini subjek juga belum menunjukkan indikator kebaruan.

Hasil pengerjaan soal nomor 2 oleh subjek CRD dapat dilihat pada gambar 3, bahwa subjek menggunakan dua cara yang berbeda. Cara pertama subjek menjumlahkan luas bangun persegi panjang dan luas dua segitiga siku-siku. Cara kedua subjek menjumlahkan luas bangun trapesium dan luas persegi panjang. Subjek dalam menyelesaikan soal tersebut memberikan lebih dari satu cara dan bernilai benar, maka subjek mampu menunjukkan indikator fleksibilitas, seperti penjelasan di atas. Akan tetapi, subjek dalam memberikan solusi atau jawaban pada soal ini belum memunculkan indikator kebaruan, dilihat bahwa jawaban yang diberikan masih terbilang umum dan tidak menunjukkan solusi yang baru walaupun sudah bernilai benar. 
Berdasarkan hasil analisa subjek CRD bergaya kognitif FI dalam menyelesaikan permasalahan hanya memunculkan indikator fleksibilitas saja, maka subjek memiliki TKBK 1 (kurang kreatif).

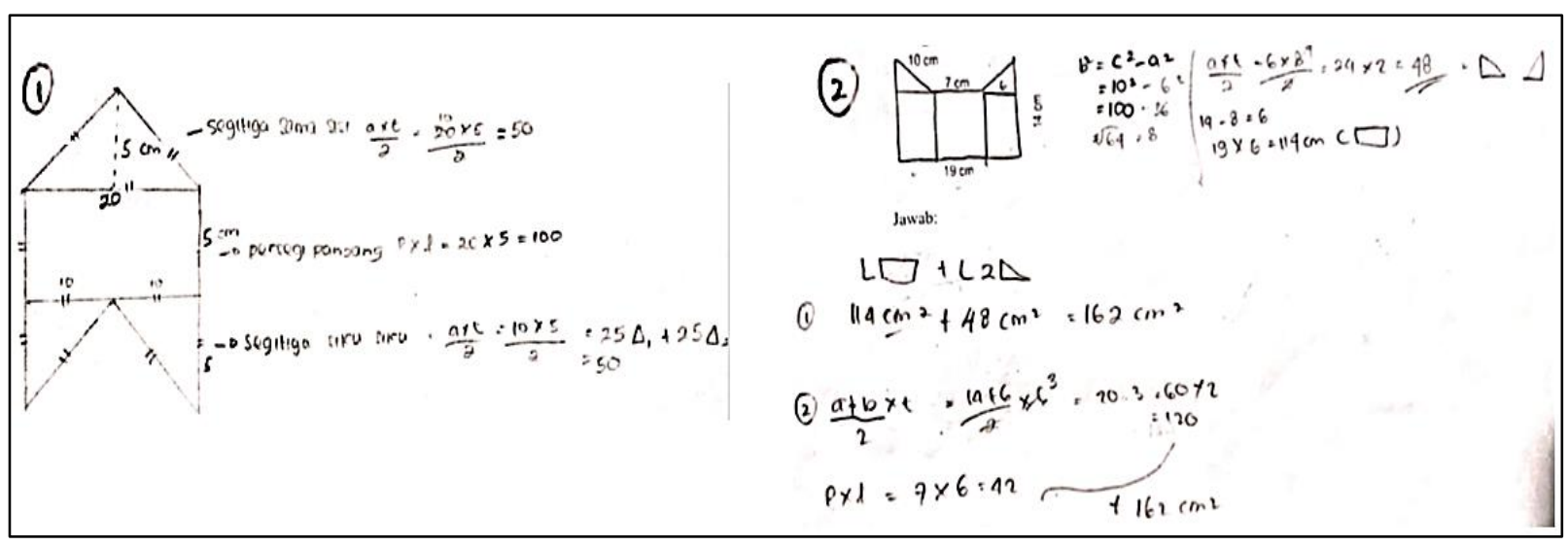

Gambar 3. Jawaban subjek CRD

\section{Subjek WDA Berkemampuan Matematika Tinggi Dengan Gaya Kognitif FD}

Pada gambar 4 tersebut dapat dilihat bahwa subjek WDA hanya mampu memberikan satu gambar gabungan bangun datar pada penyelesaian soal nomor 1 yang terdiri dari satu segitiga, dua persegi dan satu persegi panjang. Hal ini menunjukkan subjek tidak fasih dan tidak menunjukkan kebaruan dalam menyelesaikan soal, dikarenakan subjek hanya memberikan satu jawaban bernilai benar namun masih terbilang umum.

Subjek WDA memakai dua cara/metode dalam menyelesaikan soal nomor 2 diperoleh luas yang sama yaitu $162 \mathrm{~cm}^{2}$ seperti terlihat pada gambar 4. Cara pertama yang subjek berikan dengan membagi bangun tersebut menjadi dua bangun segitiga dan satu bangun persegi panjang. Cara kedua subjek WDA membagi bangun pada soal menjadi beberapa bangun yaitu trapesium dan persegi panjang, untuk selanjutnya subjek menghitung masing-masing luas bangun tersebut dengan pengetahuan awal yang sudah dipelajarinya. Hal tersebut menunjukkan subjek WDA mampu memberikan dua cara yang berbeda dan bernilai benar, maka dapat dikatakan subjek mampu menunjukkan indikator fleksibilitas dalam menyelesaikan permasalahan. Namun, dari kedua jawaban tersebut tidak ada solusi asli dan baru yang diberikan subjek WDA, ini berarti bahwa subjek WDA belum mampu menunjukkan indikator kebaruan dalam menyelesaikan soal tersebut.

Berdasarkan hasil analsa subjek WDA yang bergaya kognitif FD hanya mampu menunjukkan indikator fleksibilitas dalam menyelesaikan permasalahan. Jadi, subjek WDA memiliki TKBK 1 (kurang kreatif). 


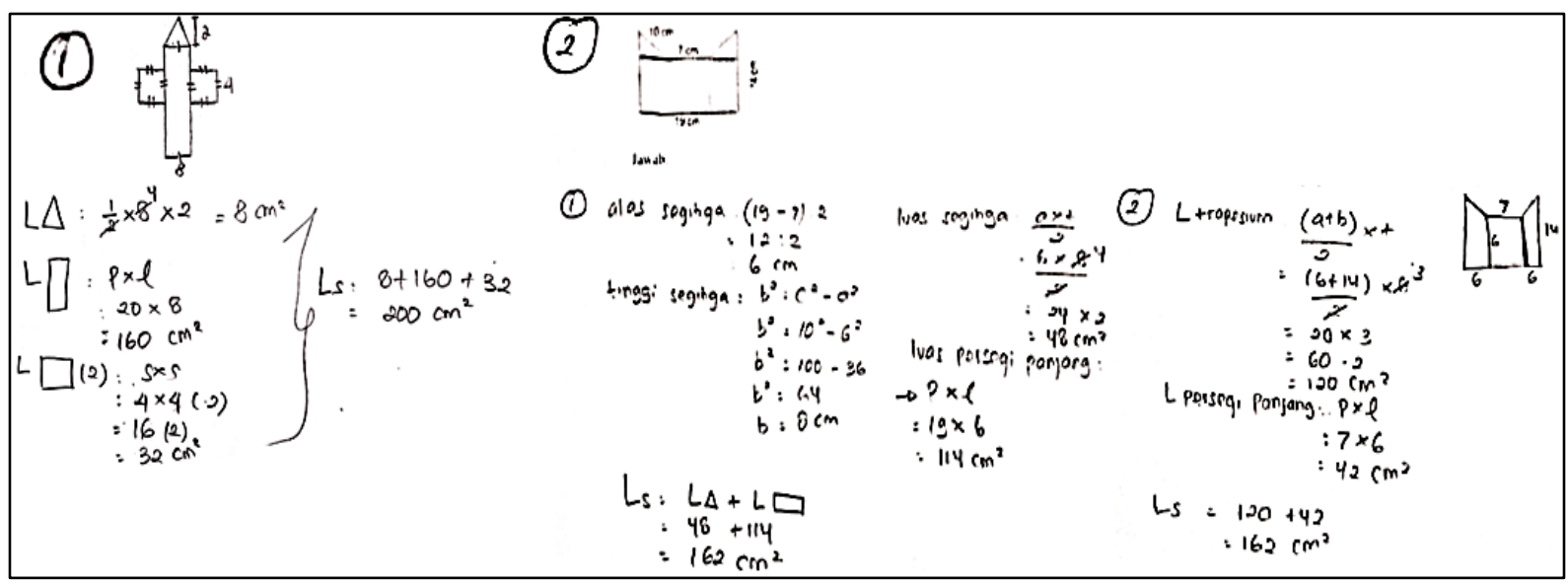

Gambar 4. Jawaban subjek WDA

\section{Subjek GAN Berkemampuan Matematika Sedang Dengan Gaya Kognitif FD}

Pengerjaan soal nomor 1 oleh subjek GAN pada gambar 5 tersebut dapat dilihat bahwa subjek mampu memahami maksud soal yaitu subjek diminta untuk menggambarkan sebuah bangun dari gabungan bangun datar dengan luas totalnya $200 \mathrm{~cm}^{2}$. Subjek GAN hanya dapat memberikan satu jawaban bernilai benar, yaitu menggambarkan sebuah bangun yang merupakan gabungan dari persegi panjang, trapesium siku-siku, dan segtiga. subjek GAN menggambarkan bangun yang tidak biasa diberikan oleh siswa pada tingkat pengetahuannya. Subjek GAN menggambar gabungan bangun datar tersebut dibuat gabungan yang terbuka antara segitiga dan dua bangun yang lainnya. Terlihat bengun segitiga tidak menempel sepenuhnya pada bangun trapesium dan persegi panjang, hanya pada bagian atas segitiga. Gambar gabungan bangun datar yang diberikan subjek GAN merupakan solusi asli dan baru yang bernilai benar. Berdasarkan hal di atas, subjek GAN tidak fasih dalam menyelesaikan soal, namun mampu memunculkan kebaruan.

Hasil pengerjaan soal nomor 2 oleh subjek GAN pada gambar 5 tersebut dapat dilihat bahwa subjek mampu menyelesaikan soal dengan dua cara/metode dengan hasil akhir yang sama. Subjek GAN mengerjakan soal dengan memecahkan bangun pada soal tersebut menjadi beberapa bangun agar dapat dihitung luasnya menggunakan pengetahuan awal yang sudah diperolehnya. Cara pertama subjek GAN menggunakan bangun pesegi panjang dan segitiga. Cara kedua subjek GAN memandang bahwa bangun tersebut merupakan gabungan dari dua bangun trapesium dan bangun pesegi panjang, maka dari itu untuk menghitung luas bangun pada soal subjek GAN menggunakan jumlah dari luas dua bangun trapesium siku-siku dan persegi panjang. Berdasarkan hal tersebut, subjek GAN dapat menunjukkan indikator fleksibilitas dalam mengerjakan soal. Namun, jawaban subjek GAN pada soal nomor 2 ini belum menunjukkan solusi yang tidak biasa diberikan siswa pada tingkat kemampuannya. Solusi yang diberikan subjek GAN terbilang masih umum, ini berarti subjek GAN belum mampu menunjukkan indikator kebaruan dalam menyelesaikan soal nomor 2. 


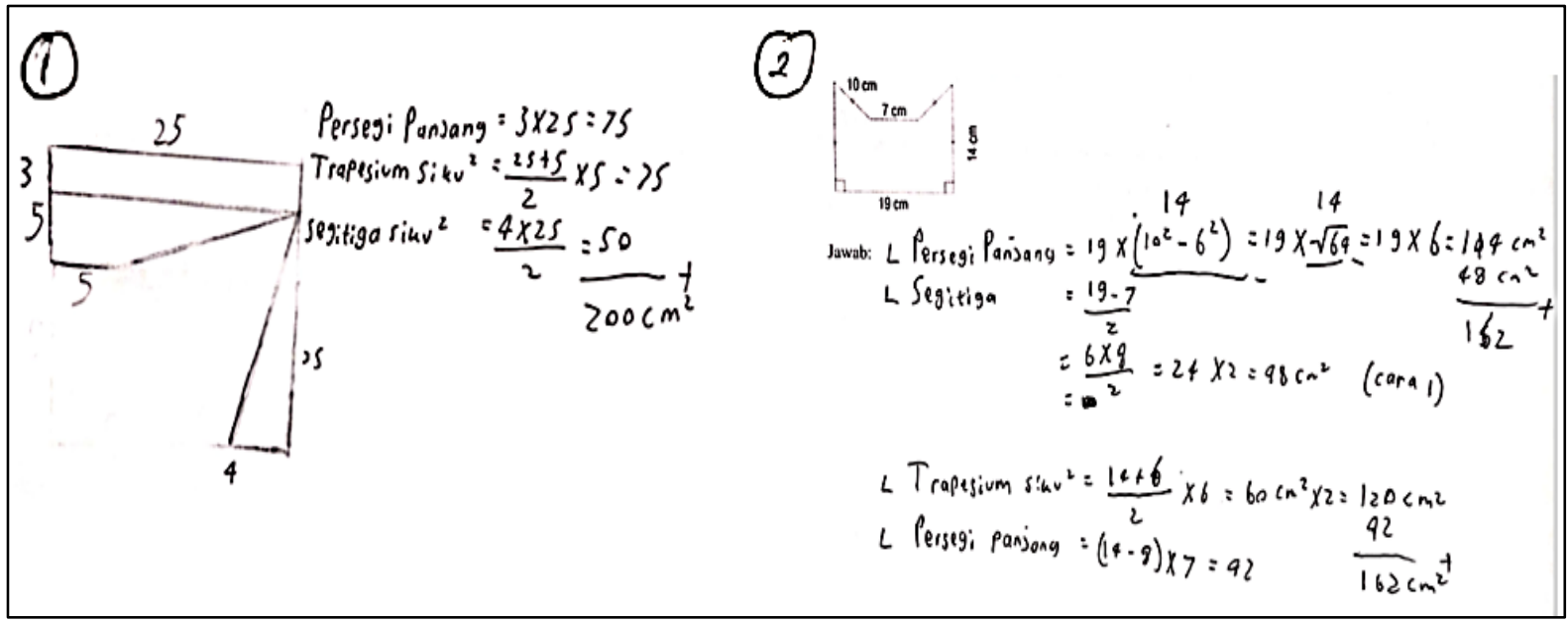

Gambar 5. Jawaban subjek $G A N$

Berdasarkan hasil analisa subjek GAN dengan gaya kognitif FD mampu menunjukkan indikator kebaruan dan fleksibilitas dalam menyelesaikan masalah luas gabungan bangun datar (segitiga dan segiempat), maka subjek GAN memiliki TKBK 3 (kreatif).

\section{Subjek MRKD Berkemampuan Matematika Rendah Dengan Gaya Kognitif FD}

Subjek MRKD dalam menyelesaikan soal nomor 1 hanya dapat memberikan satu jawaban yang bernilai benar dan terbilang masih umum terlihat pada gambar 6 di atas. Subjek MRKD menggambarkan satu bangun yang terdiri dari satu bangun segitiga dan satu bangun persegi. Berdasarkan hal tersebut, subjek MKRD belum menunjukkan indikator kefasihan maupun kebaruan dalam menyelesaikan soal nomor 1 .

Hasil pengerjaan soal nomor 2 oleh subjek MRKD pada gambar 6 tersebut dapat dilihat bahwa subjek memberikan dua cara yang berbeda, cara pertama subjek menghitung luas dengan menggunakan dua bangun segitiga dan satu bangun persegi panjang. Cara kedua subjek MKRD membagi bangun pada soal menjadi bangun layang-layang dan trapesium, sehingga subjek dapat menghitung luasnya dengan pengetahua awal yang sudah diperolehnya. Cara kedua yang diberikan oleh subjek MRKD ini terbilang solusi yang asli dan baru yang bernilai benar atau tidak biasa diberikan oleh siswa pada tingkat pengetahuannya. Hal ini dikarenakan, subjek mampu memecahkan bangun pada soal menjadi bangun yang berbeda dari siswa lainnya dan masih termasuk dalam bangun datar (segitiga dan segiempat). Subjek membagi bangun pada soal dengan membuat garis bantu dan menemukan bangun trapesium dibagian tengah serta bentuk bangun layang-layang di sebelah kanan dan kiri trapesium tersebut. Sehingga, subjek dapat menghitung luas bangun pada soal dengan menggunakan rumus luas layanglayang dan trapesium. Hasil pengerjaan soal nomor 2 tersebut, menunjukkan bahwa subjek MRKD mampu menunjukkan indikator fleksibilitas dan kebaruan.

Berdasarkan hasil Analisa, subjek MRKD yang bergaya kognitif FD mampu menunjukkan indikator fleksibilitas dan kebaruan, namun tidak memunculkan indikator kefasihan dalam menyelesaikan permasalah. Jadi, subjek MRKD memiliki TKBK 3 (kreatif). 


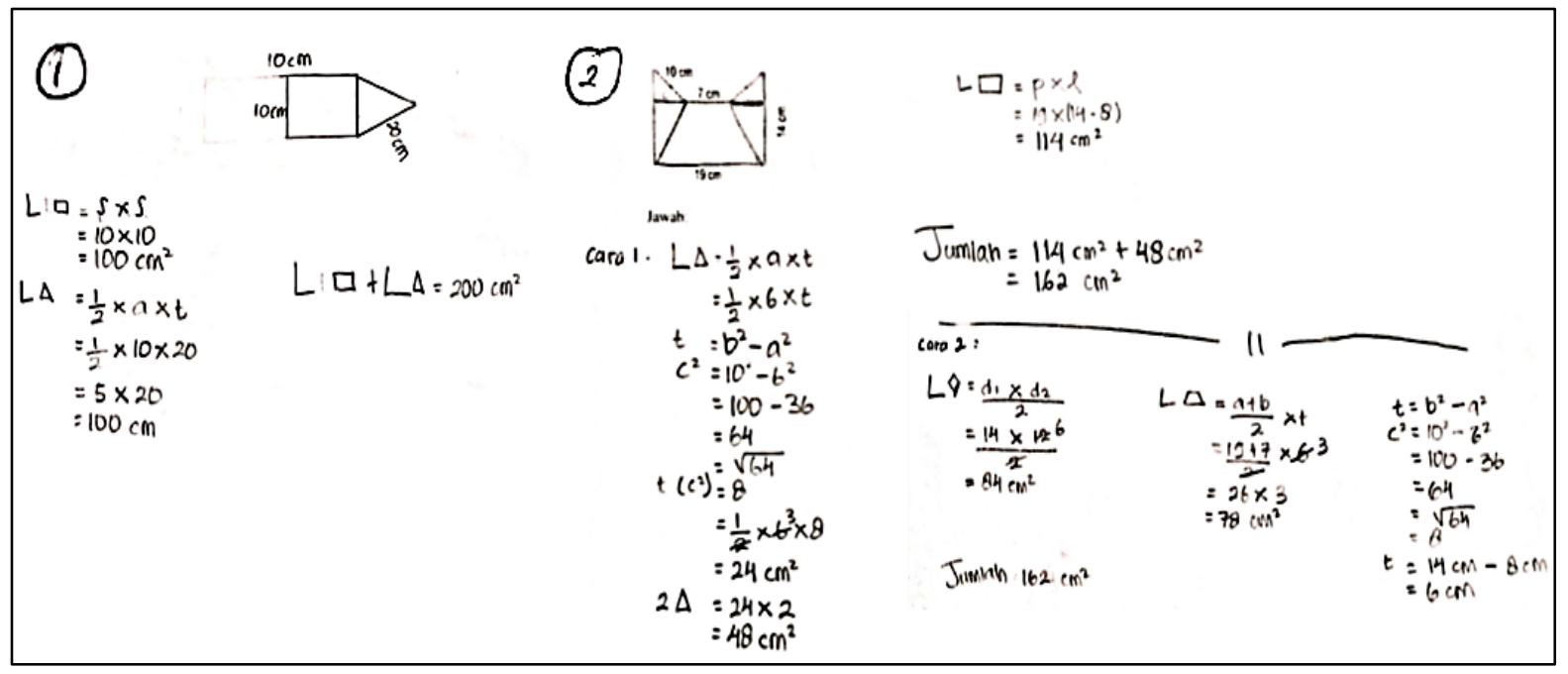

Gambar 6. Jawaban subjek MRKD

\section{KESIMPULAN}

Hasil penelitian diperoleh perbedaan Tingkat Kemampuan Berpikir Kreatif masing-masing subjek dengan gaya kognitif yang dimiliki, baik gaya kognitif Field Dependent (FD) dan Field Independent (FI). Kelima kategori Tingkat Kemampuan Berpikir Kreatif (TKBK) yang digunakan peneliti, hanya terdapat 3 kategori TKBK yang dipenuhi oleh 3 subjek FI dan 3 subjek FD dengan kemampuan matematika rendah, sedang, dan tinggi, yaitu TKBK 1 (kurang kreatif), TKBK 2 (cukup kreatif), dan TKBK 3 (kreatif). Dua subjek bergaya kognitif FI memiliki TKBK yang sama, yaitu subjek DHS dengan kemampuan matematika tinggi dan subjek VSW dengan kemampuan matematika sedang memiliki TKBK 2 (cukup kreatif). Hal ini dikarenakan dalam menyelesaikan permaslahan pada soal subjek DHS dan VSW hanya mampu menunjukkan dua indikator berpikir kreatif yaitu indikator fleksibilitas dan kefasihan. Sedangkan subjek CRD bergaya kognitif FI dengan kemampuan matematika rendah dan subjek WDA bergaya kognitif FD dengan kemampuan matematika tinggi, memunculkan indikator fleksibilitas saja dalam menyelesaikan soal. Hal ini menunjukkan bahwa subjek CRD dan WDA memiliki TKBK 1 (kurang kreatif). Dua subjek lainnya yang bergaya kognitif FD, yaitu subjek GAN dengan kemampuan matematika sedang dan subjek MRKD berkemampuan matematika rendah memiliki TKBK yang sama, yaitu TKBK 3 (kreatif). Hal ini dikarenakan subjek GAN dan MRKD mampu memunculkan indikator kebaruan dan fleksibilitas dalam menyelesaikan permasalahan pada soal.

Berdasarkan hasil diskirpsi di atas diharapkan guru dalam memberikan perlakuan terhadap siswa dalam pembelajaran perlu disesuaikan dengan tingkat kemampuan berpikir kreatif yang dimiliki siswa, sehingga perkembangan potensi diri siswa lebih maksimal. Oleh sebab itu, guru perlu mempersiapkan diri dengan sebaik mungkin dalam pembelajaran. Bagi siswa diharapkan semakin giat melatih kemampuan berpikir kreatif yang dimiliki agar mampu menyelesaikan setiap permasalahan yang dihadapi dalam belajar. 


\section{DAFTAR PUSTAKA}

Argarini, D. F., Budiyono, \& Sujadi, I. (2014). Karakteristik Berpikir Kreatif Siswa Kelas VII SMP N 1 Kragan dalam Memecahkan dan Mengajukan Masalah Matematika Materi Perbandingan Ditinjau dari Gaya Kognitif. JMEE, IV (2), 1-12.

Depdiknas. (2013). Peraturan Pemerintah Republik Indonesia.

Ghufron, M. N., \& Risnawita, R. (2012). Gaya Belajar Kajian Teoritik. Pustaka Pelajar. Yogyakarta. Kristanto, B. R., Kriswandani, \& Ratu, N. (2016). Analisis Proses Berpikir dalam Menyelesaikan Soal Geometri Ditinjau dari Gaya Kognitif Field Independent dan Field Dependent pada Siswa Kelas VIII SMP Negeri 4 Boyolali. Satya Widya. (Online) (http://repository.uksw.edu/bitstream/123456789/9859/2/T1_202012056_Full text.pdf), diakses 30 Mei 2019

Permendikbud. (2016). Tentang Kompetensi Inti dan Kompetensi Dasar Pelajaran pada Kurikulum 2013.

Putri, M. W. T., \& Ratu, N. (2018). Analisis Tingkat Berpikir Kreatif Siswa dalam Menyelesaikan Soal Luas Gabungan pada Materi Bangun Datar di SMP Negeri 8 Salatiga Kelas VII. Jurnal Pendidikan Berkarakter, 1(1), 103-109.

Rahmatina, S., Sumarmo, U., \& Johar, R. (2014). Tingkat Berpikir Kreatif Siswa dalam Menyelesaikan Masalah Matematika Berdasarkan Gaya Kognitif Reflektif dan Impulsif. Jurnal Didaktik Matematika, 1, 62-70.

Santoso, H. R. W., Ratu, N., \& Yunianta, T. N. H. (2014). Deskripsi Tingkat Kemampuan Berpikir Kreatif (TKBK) pada Materi Segiempat Siswa Kelas VII SMP Negeri 1 Pabelan Kabupaten Semarang. Satya Widya, 30(2), 82-95. https://doi.org/10.24246/j.sw.2014.v30.i2.p82-95

Silver, E. A. (1997). Fostering Creativity through Instruction Rich in Mathematical Problem Solving and Problem Posing. ZDM-The International Journal on Mathematics Education, 29 (3), 75-80.

Siswono, T. Y. E. (2006). Implementasi Teori Tentang Tingkat Berpikir Kreatif dalam Matematika. (Online) (https://tatagyes. files. wordpress. com/2007/10/tatag_jurnal_unej. pdf)

Siswono, T. Y. E. (2011). Level Of Student's Creative Thinking In Classroom Mathematics. Educational Research and Review, 6(7), 548-553. (Online) (http://www.academicjournals.org/ERR) diakses 12 Februari 2019.

Sugiyono. (2012). Metode Penelitian Kuantitatif, Kualitatif dan R\&D. Alfabeta. Bandung. 